\title{
Cigarette Smoke Can Activate the Alternative Pathway of Complement In Vitro by Modifying the Third Component of Complement
}

\author{
Richard R. Kew, Berhane Ghebrehiwet, and Aaron Janoff \\ Departments of Pathology and Medicine, Health Sciences Center, State University of New York at Stony Brook, New York 11794
}

\begin{abstract}
Cigarette smoking is associated with significant increases in the number of pulmonary mononuclear phagocytes and neutrophils. A potent chemoattractant for these cells is $\mathrm{C5a}$, a peptide generated during complement $(C)$ activation. We, therefore, investigated the possibility that cigarette smoke could activate the complement system in vitro. Our results show that factor(s) (mol wt $<1,000$ ) present in an aqueous solution of whole, unfiltered cigarette smoke can deplete the hemolytic capacity of whole human serum in a dose-dependent manner. The particle-free, filtered gas phase of cigarette smoke is inactive. The smoke factor(s) do not activate serum $\mathrm{C1}$, but do deplete serum $\mathrm{C} 4$ activity. Treatment of purified human $\mathrm{C} 3$ with whole smoke solution modifies the molecule such that its subsequent addition to serum (containing Mg/EGTA to block the classical pathway) results in consumption of hemolytic complement by activation of the alternative pathway. Smoke-modified C3 shows increased anodal migration in agarose electrophoresis, but this is not due to proteolytic cleavage of the molecule as evidenced by sodium dodecyl sulfate-polyacrylamide gel electrophoresis. In contrast to methylamine-treated C3, C3 treated with smoke is only partially susceptible to the action of the complement regulatory proteins Factors $\mathrm{H}$ and $\mathbf{I}$. In addition, smoke-modified $\mathrm{C} 3$ has diminished binding to Factor $\mathrm{H}$ as compared with methylamine-treated C3. Finally, smoke-modified $\mathrm{C} 3$ incorporates $\left[{ }^{14} \mathrm{C}\right]$ methylamine which suggests that the thiolester bond may be intact.

These data indicate that aqueous whole cigarette smoke solution can modify $\mathrm{C3}$ and activate the alternative pathway of complement, perhaps by a previously unrecognized mechanism. Should this occur in vivo, complement activation might partly account for the extensive pulmonary leukocyte recruitment observed in smokers.
\end{abstract}

\section{Introduction}

Cigarette smoking has been identified as the major causative factor in the development of pulmonary emphysema (1), but little is known of how cigarette smoke actually contributes to

This work was submitted by $R$. Kew in partial fulfillment of the requirements for the Ph.D. degree in Basic Health Sciences (Experimental Pathology) from the State University of New York at Stony Brook.

Address correspondence and reprint requests to Dr. Aaron Janoff, Department of Pathology, Health Sciences Center, SUNY at Stony Brook, NY 11794.

Received for publication 30 May 1984 and in revised form 22 October 1984.

J. Clin. Invest.

(C) The American Society for Clinical Investigation, Inc.

0021-9738/85/03/1000/08 \$1.00

Volume 75, March 1985, 1000-1007 the pathogenesis of the disease. The characteristic histopathologic observation in the emphysematous lung is excessive tissue dissolution which is thought to result from an unrestrained proteolytic attack on lung interstitium, particularly the elastic fibers (reviewed in 2,3). Neutrophils and mononuclear phagocytes (alveolar macrophages and monocytes) have been implicated as the source of this increased protease (primarily elastase) burden (4-6). The lungs of cigarette smokers are known to contain significantly increased numbers of these elastase-bearing phagocytes $(7,8)$, but the mechanism of this smoke-induced leukocyte recruitment is poorly understood.

Recently, efforts have focused on mechanisms whereby cigarette smoke may indirectly recruit phagocytic cells into the lung. Many of these studies have examined the elaboration of neutrophil chemoattractants by stimulated alveolar macrophages of smokers (9-12). In addition, proteolytic destruction of lung connective tissue may, in itself, contribute to the leukocyte recruitment. For example, proteolytically generated fragments of collagen (13) and fibronectin (14) have been demonstrated to be chemotactic for peripheral blood monocytes, and incubation of human elastin with neutrophil elastase results in the production of biologically active peptides which are also chemotactic for neutrophils and monocytes (15).

Less attention, however, has been paid to the possibility that leukocyte chemoattractants may be generated in the lung fluids of smokers as a direct result of complement (C) activation by inhaled cigarette smoke. It is well documented that when the complement cascade is activated, the fifth component of complement (C5) is proteolytically cleaved, resulting in generation of the chemotactically active peptide C5a (reviewed in 16). C5a is one of the most potent neutrophil and monocyte chemoattractants yet described and is biologically active at picogram quantities. Moreover, a recent report demonstrates that physiological concentrations of nicotine enhance neutrophil responsiveness to $\mathrm{C5a}$ (17).

We reported earlier that rats acutely exposed to cigarette smoke had significantly increased levels of chemotactic activity for neutrophils and monocytes in their lung fluids. However, prior depletion of circulating complement by treatment of the animals with cobra venom factor prevented this smoke-induced chemotactic activity (18). In addition, others have recently demonstrated consumption of complement hemolytic activity in serum following its incubation with cigarette smoke condensate $(19,20)$. Although suggestive, our preliminary studies

1. Abbreviations used in this paper: $\mathrm{C}$, complement; $\mathrm{E}_{\mathrm{R}}$, unsensitized rabbit erythrocytes; EA, sheep erythrocytes coated (sensitized) with goat anti-sheep erythrocyte antibody; EAC1, EA coated with human $\mathrm{Cl}$; EAC3b, sheep erythrocytes coated with human C3b; $\mathrm{GVB}^{2+}$, isotonic veronal-buffered saline ( $\mathrm{pH} 7.4)$ containing $0.15 \mathrm{mM} \mathrm{CaCl}_{2}$, $0.5 \mathrm{mM} \mathrm{MgCl}_{2}$, and $0.1 \%$ gelatin; $\mathrm{Mg}-\mathrm{GVB}$, isotonic veronal-buffered saline ( $\mathrm{pH} 7.4$ ) containing $0.5 \mathrm{mM} \mathrm{MgCl}_{2}$ and $0.1 \%$ gelatin; NHS, normal human serum; SDS-PAGE, sodium dodecyl sulfate-polyacrylamide gel electrophoresis. 
and the others referred to above did not explore possible chemical mechanisms of complement activation by cigarette smoke.

Therefore, we undertook in vitro studies to investigate the effect of cigarette smoke on serum complement and purified complement components. In the present report, we show that incubation of whole human serum with an aqueous solution of unfiltered cigarette smoke depletes hemolytic activity. Serum $\mathrm{Cl}$ was not activated under these conditions; however, purified C3 preincubated with smoke solution and subsequently added to serum (containing $5 \mathrm{mM} \mathrm{Mg-EGTA}$ to block the classical pathway) did activate complement. These and other results to be discussed below suggest that aqueous cigarette smoke components are capable of triggering the alternative pathway of complement, probably by modifying $\mathrm{C} 3$.

\section{Methods}

Buffers. Buffers used were as follows: Dulbecco's phosphate-buffered saline (PBS), $\mathrm{pH}$ 7.2; isotonic veronal-buffered saline (VB), $\mathrm{pH}$ 7.4; VB containing $0.15 \mathrm{mM} \mathrm{CaCl} 2$ and $0.5 \mathrm{mM} \mathrm{MgCl}_{2}\left(\mathrm{VB}^{2+}\right)$; $\mathrm{VB}^{2+}$ containing $0.1 \%$ gelatin $\left(\mathrm{GVB}^{2+}\right)$; VB containing $0.1 \%$ gelatin and 0.01 M EDTA (GVB-E); $\mathrm{GVB}^{2+}$ containing $2.5 \%$ (wt/vol) sucrose $\left(\mathrm{SGVB}^{2+}\right.$ ); $0.1 \mathrm{M} \mathrm{MgCl}_{2}, 0.1 \mathrm{M}$ EGTA adjusted to $\mathrm{pH} 7.0$ (Mg-EGTA); and VB containing $0.5 \mathrm{mM} \mathrm{MgCl}$ and $0.1 \%$ gelatin (Mg-GVB).

Purified complement proteins. Highly purified $\mathrm{C} 3$ was isolated using the method of Tack and Prahl (21). The C3 was then further purified by passage over a Sepharose 4B (Pharmacia Fine Chemicals, Inc., Piscataway, NJ) affinity column containing immobilized goat IgG antibodies (Dako Corp., Santa Barbara, CA) to human IgA, IgG, and IgM in order to remove traces of contaminating immunoglobulins. Small amounts of $\mathrm{C} 3 \mathrm{~b}$ and $\mathrm{C} 3\left(\mathrm{H}_{2} \mathrm{O}\right)$ were finally removed by chromatography on QAE-Sephadex (Pharmacia Fine Chemicals, Inc., Piscataway, NJ) according to the method of Janatova et al (22). C3 preparations were routinely rechromatographed on QAE-Sephadex after prolonged storage at $-85^{\circ} \mathrm{C}$ to remove the accumulated $\mathrm{C} 3\left(\mathrm{H}_{2} \mathrm{O}\right)$. Such purified $\mathrm{C} 3$ contained no immunochemically detectable C5.

C3b was generated from purified C3 $(2 \mathrm{mg} / \mathrm{ml})$ by the addition of $1 \%$ (wt/wt) L-(tosylamido 2-phenyl)ethyl chloromethyl ketone-treated trypsin (Worthington Biochemical Co., Freehold, NJ) for $2.5 \mathrm{~min}$ at $22^{\circ} \mathrm{C}$ followed by $2 \%$ (wt/wt) soybean trypsin inhibitor (Sigma Chemical Co., St. Louis, MO) to stop the reaction.

Factors $\mathrm{H}$ and I were purified as described (23). The highly purified Factor $\mathrm{H}$ used in our binding experiment (see below) was a generous gift from Dr. Michael Pangburn (Scripps Clinic and Research Foundation, La Jolla, CA).

Aggregated IgG. Human IgG was first isolated from serum by a single step procedure using DEAE Affi-Gel Blue, according to the manufacturer's specifications (Bio-Rad Laboratories, Inc., Richmond, CA). IgG was then aggregated by incubation at $63^{\circ} \mathrm{C}$ for $20 \mathrm{~min}$ at a concentration of $10 \mathrm{mg} / \mathrm{ml}$, as described (24). Particulate aggregates were removed by centrifugation at $200 \mathrm{~g}$ for $5 \mathrm{~min}$ and the supernate was used as soluble, aggregated IgG.

Sera and antisera. A pool of normal human serum (NHS) was obtained from young, apparently healthy, nonsmoking volunteers.

Monospecific, polyvalent antisera to $\mathrm{Clq}, \mathrm{C3}$, and $\mathrm{C} 4$ were raised in New Zealand White rabbits by multiple subcutaneous and intramuscular injections of $0.1 \mathrm{mg}$ of purified antigen in Freund's complete adjuvant. Antihuman C3 was also purchased from Cappel Laboratories (West Chester, PA). Antisera to Clr and C1s were raised in goats, and also purchased from Atlantic Antibodies (Scarborough, ME).

Protein determinations. Protein concentrations were determined by the method of Lowry (25) using bovine serum albumin as a reference standard. The concentration of $\mathrm{C} 3$ was also determined by measuring absorbance at $280 \mathrm{~nm}$ using an $E_{1}^{1 \%}$ of 9.7 as previously described (21).
Preparation of smoke solutions. Whole, aqueous, cigarette smoke solutions were prepared by a modification of the method of Carp and Janoff (26). The smoking apparatus consisted of a 50-ml plastic syringe fitted with a 3-way stopcock (Pharmaseal K-75, American Hospital Supply, Edison, NJ) to which the cigarette and a $0.1-\mathrm{ml}$ glass capillary tube were attached. The capillary tube was placed into a $4-\mathrm{ml}$ plastic tube containing $1.0 \mathrm{ml}$ of PBS, and the tube was immersed in a $37^{\circ} \mathrm{C}$ water bath. All materials used in the preparation of smoke solutions (i.e., syringe, 3-way stopcock, capillary tube, plastic tube, and PBS) were sterile, pyrogen-free, and used only once. Smoke solutions were prepared using 2R1 Kentucky Reference cigarettes (a generous gift from Dr. D. Layton Davis, Tobacco and Health Research Institute, University of Kentucky, Lexington, KY) which were stored at $-85^{\circ} \mathrm{C}$. Before use, the cigarettes were thawed, and then rehumidified for 24 $h$ at $60 \%$ relative humidity in a sealed chamber at room temperature. The smoking regimen, based on the standard smoking cycle (27), was as follows: $35 \mathrm{ml}$ of tobacco smoke was drawn into the syringe in a 2-s puff and then slowly bubbled into the buffer. One puff of smoke per minute was drawn until a 5-cm butt length of cigarette was consumed (usually eight or nine puffs). In this manner, the smoke of six cigarettes was bubbled through $1.0 \mathrm{ml}$ of $\mathrm{PBS}$ at $37^{\circ} \mathrm{C}$, after which the solution was decanted to a new tube to remove the accumulated tar and large particulate matter. Since the final smoke solutions were slightly acidic, the $\mathrm{pH}$ was readjusted with $1.0 \mathrm{~N} \mathrm{NaOH}$ to match that of the starting buffer. Smoke solutions prepared in this manner varied only $\pm 10 \%$ in their ability to consume $50 \%$ of serum complement.

In some experiments, the whole aqueous smoke solutions were exhaustively dialylzed before use against PBS at $4^{\circ} \mathrm{C}$ using Spectra-Por 6 dialysis tubing (mol wt limit $=1000$; Spectrum Medical Industries, Inc., Los Angeles, CA) and these were designated as dialyzed smoke solutions. Aqueous solutions of the particle-free, gas phase of cigarette smoke were also prepared exactly as described above except that a Cambridge filter pad (44-mm diam, 1.5-mm thick, $0.22 \mu \mathrm{m}$ pore size; Phipps and Bird, Inc., Richmond, VA) was inserted between the cigarette and the 3-way stopcock. The filter pad was replaced after each cigarette was consumed.

Aliquots of each smoke solution were tested for endotoxin contamination using the Limulus Amebocyte Lysate kit (M. A. Bioproducts, Walkersville, MD) and were found to be negative. After preparation, all smoke solutions were either stored at $-85^{\circ} \mathrm{C}$ or used immediately.

Treatment of $\mathrm{C} 3$ and NHS with smoke solutions. Purified $\mathrm{C} 3$ and NHS were treated with smoke solutions, methylamine, or PBS (the amounts are described in the appropriate section of Results) for $\mathbf{6 0}$ min at $37^{\circ} \mathrm{C}$. The mixtures were then exhaustively dialyzed against PBS at $4^{\circ} \mathrm{C}$, using a dialysis membrane with a mol wt limit of 50,000 (Spectrum Medical Industries, Inc.), to remove unreacted, dialyzable smoke components or excess methylamine. Preparations were stored at $-85^{\circ} \mathrm{C}$ or used immediately.

Electrophoretic procedures. C3 and NHS, treated as above, were electrophoresed at $3-4 \mathrm{~V} / \mathrm{cm}$ for $2.5 \mathrm{~h}$ at room temperature in $1 \%$ agarose (Seakem LE, FMC Corp., Rockland, ME) using $0.1 \mathrm{M}$ barbital buffer ( $\mathrm{pH}$ 8.6). After electrophoresis, $\mathrm{C} 3$ was visualized with a monospecific, polyvalent antihuman C3. Electrophoresis in polyacrylamide gel containing sodium dodecyl sulfate (SDS-PAGE) was performed according to the method of Laemmli (28). Staining of gels for proteins was performed using Coomassie Brilliant blue R-250 or Amido black 10B (Bio-Rad Laboratories, Inc.).

Hemolytic assays. Sheep erythrocytes sensitized with rabbit antisheep erythrocyte antibody (EA) and EA coated with human $\mathrm{C1}$ (EAC1) were prepared according to established methods (29). Materials used in the preparation of EA and EACl were purchased from Cordis Laboratories, Inc. (Miami, FL). Unsensitized rabbit erythrocytes $\left(E_{R}\right)$ were freshly isolated from a New Zealand White rabbit and then washed several times with cold Mg-GVB. Hemolytic titration of serum C4 was performed as previously described (29). Depletion of serum hemolytic activity was measured by adding various amounts of smoke solutions, methylamine, and/or PBS to $0.1 \mathrm{ml}$ of NHS so that the final volume of the mixture was $0.2 \mathrm{ml}$. After a $60-\mathrm{min}$ incubation at 
$37^{\circ} \mathrm{C}, 0.02 \mathrm{ml}$ of the reaction mixture was removed and added to 0.1 $\mathrm{ml}$ of EA $\left(5 \times 10^{8} / \mathrm{ml}\right)$, the volume was adjusted to $0.4 \mathrm{ml}$ with $\mathrm{GVB}^{2+}$, and the incubation was continued for an additional $60 \mathrm{~min}$ at $37^{\circ} \mathrm{C}$. The hemolytic reaction was terminated by adding $1.6 \mathrm{ml}$ of ice-cold $\mathrm{GVB}^{2+}$, the mixtures were centrifuged, and the percentage of hemolysis was measured as the absorbance of free hemoglobin in the supernate at $412 \mathrm{~nm}$. The percent lysis of EA incubated with $0.01 \mathrm{ml}$ of untreated NHS was used as a reference for $0 \%$ depletion of hemolytic activity. Since whole smoke solution has its own color, all hemolytic assays had smoke-color controls consisting of smoke solution, EA, and $\mathrm{GVB}^{2+}$. This absorbance value was subtracted from the smoke-treated experimental samples.

Activation of the alternative pathway was measured by pretreating $0.05 \mathrm{ml}$ of purified C3 $(1 \mathrm{mg} / \mathrm{ml})$ with various amounts of smoke solutions, methylamine, and/or PBS so that the final volume was 0.1 ml. Following a $60-\mathrm{min}$ incubation at $37^{\circ} \mathrm{C}, 0.1 \mathrm{ml}$ of NHS containing $5 \mathrm{mM} \mathrm{Mg-EGTA}$ was added to each mixture and the reaction was allowed to proceed for an additional $60 \mathrm{~min}$ at $37^{\circ} \mathrm{C}$. Next, $0.1 \mathrm{ml}$ of each mixture was removed and added to $0.1 \mathrm{ml}$ of $E_{R}\left(5 \times 10^{8} / \mathrm{ml}\right)$, the volume was adjusted to $0.4 \mathrm{ml}$ with $\mathrm{Mg}-\mathrm{GVB}$, and the incubation continued at $37^{\circ} \mathrm{C}$ for $60 \mathrm{~min}$. The reaction was stopped by addition of $1.0 \mathrm{ml}$ of ice-cold Mg-GVB. After a low speed centrifugation, the absorbance of the supernate was measured as before at $412 \mathrm{~nm}$.

Immunochemical determination of $\mathrm{Cl}$ activation in serum. NHS was incubated with an equal volume of whole smoke solution, PBS, or aggregated IgG $(2 \mathrm{mg} / \mathrm{ml})$ for $60 \mathrm{~min}$ at $37^{\circ} \mathrm{C}$. These mixtures were then analyzed by single radial immunodiffusion against anti-C1r. The immunodiffusion slides contained $1 \%$ agarose in $0.03 \mathrm{M}$ potassium phosphate (pH 8.0), $0.1 \mathrm{M} \mathrm{NaCl}$, and $0.01 \mathrm{M}$ EDTA, and the appropriate dilution of anti-Clr as previously described (30). Double (Ouchterlony) immunodiffusion analysis was also carried out on these samples using $0.8 \%$ agarose in veronal-buffered saline ( $\mathrm{pH} 7.2$ ) containing $2.5 \mathrm{mM} \mathrm{CaCl}$ and $0.09 \mathrm{M} \mathrm{NaCl}$, and precipitin lines were developed with monospecific, polyvalent antihuman $\mathrm{Clq}, \mathrm{Clr}$, and $\mathrm{Cls}$.

Effect of Factors $H$ and $I$ on treated $C 3$. Samples of $\mathrm{C} 3,0.1 \mathrm{ml}$ at $1.6 \mathrm{mg} / \mathrm{ml}$, were treated as above with smoke solution, methylamine, or PBS. The treated C3 $(160 \mu \mathrm{g})$ was then reacted for $45 \mathrm{~min}$ at $37^{\circ} \mathrm{C}$ with physiological concentrations of Factors $\mathrm{H}(50 \mu \mathrm{g})$ and I $(3.4 \mu \mathrm{g})$ in a total volume of $0.2 \mathrm{ml}$. C3 cleavage products were subsequently visualized by SDS-PAGE under reducing conditions.

Binding of Factor $\mathrm{H}$ to treated $\mathrm{C3}$. Factor $\mathrm{H}$ was radioiodinated $\left(0.5 \mathrm{mCi} / \mathrm{mg}\right.$ ) using ${ }^{125} \mathrm{I}-\mathrm{Bolton}-H u n t e r$ reagent (New England Nuclear, Boston, MA) according to the manufacturer's specifications. Sheep erythrocytes coated with C3b (EC3b) were prepared as described in (31). A competitive ${ }^{125}$ I-labeled Factor $\mathrm{H}$ binding assay was then carried out to test for activated $\mathrm{C} 3$ after treatment with smoke solution, methylamine, or PBS, according to the method of Pangburn and Müller-Eberhard (32). C3b, generated by treating C3 with trypsin (see above), was used as the positive control in this assay.

Treatment of $C 3$ with radiolabeled methylamine or iodoacetamide. $0.5 \mathrm{ml}$ of $\mathrm{C} 3(2.5 \mathrm{mg} / \mathrm{ml})$, pretreated with smoke solution, methylamine, or PBS as described above, was reacted with $4 \mathrm{mM}\left[{ }^{14} \mathrm{C}\right]$ methylamine ( $46 \mathrm{mCi} / \mathrm{mmol}$; New England Nuclear) for $4 \mathrm{~h}$ at $37^{\circ} \mathrm{C}$. Excess isotope was subsequently removed by dialysis against PBS at $4^{\circ} \mathrm{C}$. Approximately $0.32 \mathrm{mg}$ of each C3 was then added to $10 \mathrm{ml}$ of Dimiscint (National Diagnostics, Somerville, NJ) and the uptake of labeled methylamine was determined by liquid scintillation counting.

Radioalkylation of C3 pretreated with smoke, methylamine, or PBS was carried out using $\left[{ }^{14} \mathrm{C}\right]$ iodoacetamide $(23.6 \mathrm{mCi} / \mathrm{mmol}$; New England Nuclear) according to the method of Janatova et al. (33).

\section{Results}

Effect of aqueous cigarette smoke on serum hemolytic activity. Fig. 1 demonstrates that aqueous, unfiltered cigarette smoke solution depletes the hemolytic capacity of NHS in a dosedependent fashion and in a manner similar to that which

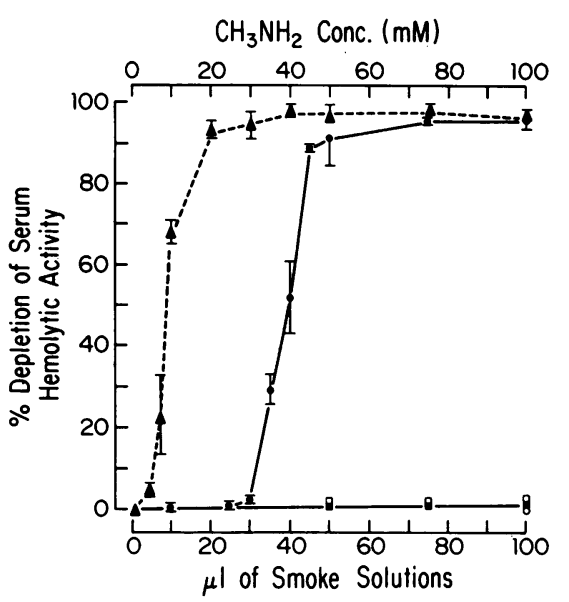

Figure 1. Depletion of serum hemolytic activity by smoke solutions or methylamine $\left(\mathrm{CH}_{3} \mathrm{NH}_{2}\right)$. The indicated volumes of smoke solutions or concentrations of methylamine were added to $0.1 \mathrm{ml}$ of NHS; PBS was added, if needed, to bring the final volume to $0.2 \mathrm{ml}$. Following an incubation at $37^{\circ} \mathrm{C}$ for $60 \mathrm{~min}, 0.02 \mathrm{ml}$ of each mixture was removed and added to $0.1 \mathrm{ml}$ of EA $\left(5 \times 10^{8} / \mathrm{ml}\right)$ and the final volume was adjusted to $0.4 \mathrm{ml}$ with $\mathrm{GVB}^{2+}$. After an additional 60 -min incubation at $37^{\circ} \mathrm{C}$, the reaction was terminated by adding $1.6 \mathrm{ml}$ of ice-cold $\mathrm{GVB}^{2+}$. Hemolysis was measured as the absorbance at $412 \mathrm{~nm}$ of free hemoglobin in the supernate. Data are expressed as the percent of serum hemolytic activity depleted, using untreated serum as the $0 \%$ reference ( $100 \%$ hemolysis). Methylamine $(---\Delta---)$; whole, aqueous smoke solution (-๑-); dialyzed smoke (- -); aqueous, gas phase of smoke (-ロー); PBS (一०-).

occurs after treatment of serum with methylamine, a nucleophile known to activate the alternative pathway of complement by cleaving the thiolester bond in C3 (31). This smoke-induced depletion is not due to endotoxin contamination because smoke solutions were determined to be endotoxin negative using the Limulus assay. In addition, loss of serum hemolytic activity is not an artifact due to direct effects of smoke on the EA, because smoke-treated and untreated EA were equally susceptible to complement-mediated lysis by NHS. Dialyzed smoke solutions (1000-mol wt limit membrane) did not deplete serum complement activity. Similarly, the particle-free, aqueous gas phase of smoke had no effect on the hemolytic capacity of NHS. Finally, nicotine, ammonia, and cyanide, which are all present in relatively large quantities in cigarette smoke, failed to deplete serum hemolytic activity over a wide range of concentrations tested.

Effect of smoke on purified C3. Since smoke appeared to diminish serum hemolytic complement activity, we chose next to examine the effect of smoke on purified C3 because (a) $\mathrm{C} 3$ is the complement component found in the highest concentration in serum and is essential for the activation of both the classical and alternative pathways, and $(b)$ smoke contains a number of substances (including methylamine) which can potentially break the thiolester bond in $\mathrm{C} 3$ and activate the alternative pathway. Fig. 2 demonstrates that incubation of purified C3 with smoke solution modified the activity of the protein such that its subsequent addition to serum caused consumption of complement. Before incubation with smoke, the $\mathrm{C} 3$ used in this experiment was rigorously purified, as described in Methods, to free it from contaminating $\mathrm{C} 3 \mathrm{~b}$ and $\mathrm{C} 3\left(\mathrm{H}_{2} \mathrm{O}\right)$, both of which can activate the alternative pathway. 


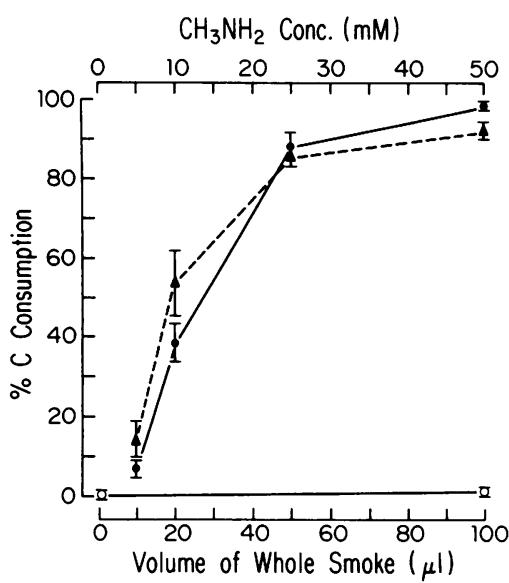

Figure 2. Effect of whole smoke and methylamine on purified C3. 50 $\mu l$ of $\mathrm{C} 3(1 \mathrm{mg} / \mathrm{ml})$ was pretreated with the indicated amounts of whole smoke solution $(-\bullet-)$, methylamine $\left(\mathrm{CH}_{3} \mathrm{NH}_{2}\right)$ $(---\Delta---)$, or PBS (-०-); the final volume of the mixtures was then adjusted to $0.1 \mathrm{ml}$ with PBS. Following a 60 -min incubation at $37^{\circ} \mathrm{C}$, mixtures were exhaustively dialyzed against PBS at $4^{\circ} \mathrm{C}$ in a $0.5-\mathrm{ml}$ conical microtube. $0.1 \mathrm{ml}$ of NHS containing $5 \mathrm{mM} \mathrm{Mg}$ EGTA was then added to each sample and incubated for $60 \mathrm{~min}$ at $37^{\circ} \mathrm{C} .0 .1 \mathrm{ml}$ of each mixture was removed and added to $0.1 \mathrm{ml}$ of $E_{R}\left(5 \times 10^{8} / \mathrm{ml}\right)$, the volume was adjusted to $0.4 \mathrm{ml}$ with $\mathrm{Mg}-\mathrm{GVB}$, and samples were incubated for an additional $60 \mathrm{~min}$ at $37^{\circ} \mathrm{C}$. Hemolysis was measured as absorbance at $412 \mathrm{~nm}$ as before. Data are expressed as the percent consumption of hemolytic $\mathrm{C}$ in $\mathrm{Mg}$ EGTA-treated serum, using untreated serum as the $0 \%$ reference (100\% hemolysis).

Such purified C3, incubated with buffer, did not activate complement upon addition to serum. Since the $\mathrm{C} 3$ plus smoke mixtures were exhaustively dialyzed through large-pore membranes before their addition to serum, the resultant complement activation was due to modified $\mathrm{C} 3$ and not to residual active smoke components, because the latter are dialyzable through 1000-mol wt limit membranes (Fig. 1). Also, because the serum contained Mg-EGTA to prevent classical pathway activation, the smoke-modified $\mathrm{C} 3$ apparently activated the alternative pathway. Under the same conditions, methylaminetreated C3 (a known activator of the alternative pathway) gave similar results (Fig. 2).

When smoke-treated C3 was examined by immunoelectrophoresis, it showed increased anodal migration similar to that of $\mathrm{C} 3 \mathrm{~b}$ (Fig. 3). The smoke-induced change in electrophoretic mobility was not due to proteolytic cleavage of $\mathrm{C} 3$ because both the alpha and beta chains of smoke-treated C3 had an identical molecular weight as those of untreated, native C3 when analyzed by SDS-PAGE under reducing conditions (Fig. 4). When NHS was treated with smoke solution (then dialyzed) and examined by immunoelectrophoresis against anti-C3, increased anodal migration of C3 was again observed (data not shown). The smoke-induced electrophoretic modification of C3 could not be reproduced by treating C3 with methylamine (Fig. 3). In addition, the filtered gas phase of smoke and dialyzed whole smoke had no effect on the electrophoretic mobility of C3 (data not shown).

Effect of smoke on serum $C 1$ and C4. To determine whether cigarette smoke solution could also activate the classical pathway, we examined the effect of smoke on $\mathrm{Cl}$ and $\mathrm{C} 4$ in whole serum. $\mathrm{Cl}$ activation was assessed by the radial immu-

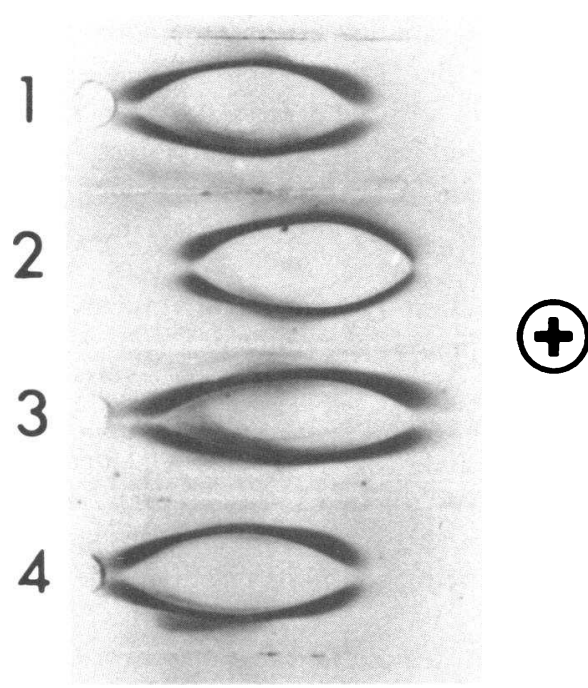

Figure 3. Electrophoretic mobility of $\mathrm{C} 3(3.2 \mathrm{mg} / \mathrm{ml})$ treated with an equal volume of PBS (1), $1 \%$ trypsin (wt/wt) for $2.5 \mathrm{~min}$ at $22^{\circ} \mathrm{C} \mathrm{(2),}$ an equal volume of whole smoke solution (3), or $50 \mathrm{mM}$ methylamine (4). Following dialysis against PBS at $4^{\circ} \mathrm{C}, \sim 25 \mu \mathrm{g}$ of $\mathrm{C} 3$ was applied to each well and electrophoresed in $1 \%$ agarose (in $0.1 \mathrm{M}$ barbital buffer, $\mathrm{pH} 8.6$ ) for $2.5 \mathrm{~h}$ at room temperature. $0.1 \mathrm{ml}$ of monospecific, polyvalent antihuman $\mathrm{C} 3$ was then added to each trough; C3 precipitates were visualized after a 12-24-h immunodiffusion period. The gel was subsequently stained with Coomassie blue after a $24-\mathrm{h}$ soak in $0.9 \% \mathrm{NaCl}$ plus $0.1 \%$ sodium azide (to remove nonprecipitated protein). Direction of $\mathrm{C} 3$ migration was toward the anode $(+)$.

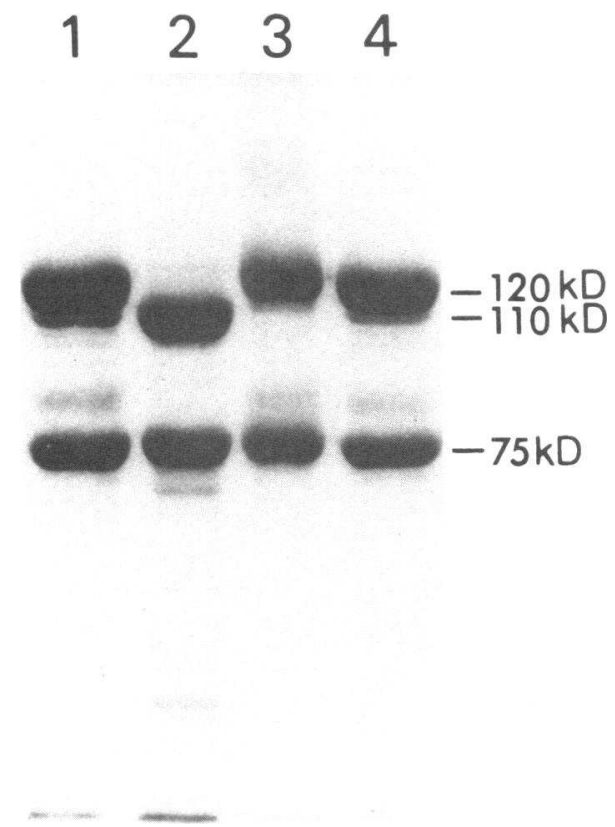

Figure 4. SDS-PAGE of $\mathrm{C} 3(3.2 \mathrm{mg} / \mathrm{ml})$ treated with an equal volume of PBS (lane 1), $1 \%$ (wt/wt) trypsin for $2.5 \mathrm{~min}$ at $22^{\circ} \mathrm{C}$ (C3b) (lane 2), an equal volume of whole smoke solution (lane 3), and $50 \mathrm{mM}$ methylamine (lane 4). Following dialysis against PBS at $4^{\circ} \mathrm{C}, \sim 25 \mu \mathrm{g}$ of $\mathrm{C} 3$ was applied to each lane and electrophoresis was carried out in $7 \%$ polyacrylamide under reducing conditions $(1 \%$ 2-mercaptoethanol). The gel was subsequently stained with Coomassie blue. The 120- and 75-kD bands are the intact alpha and beta chains of C3, respectively. The alpha chain of C3b (alpha') is decreased by proteolytic cleavage to $110 \mathrm{kD}$. 
nodiffusion method developed by Ziccardi and Cooper (30). This technique is based on the fact that $\mathrm{Cl}$ inactivator $(\mathrm{C} \overline{1}-$ INA) binds to $\mathrm{C} \overline{1} \mathrm{r}$ (but not the zymogen, $\mathrm{Clr}$ ) when $\mathrm{Cl}$ is activated in serum. The resultant enzyme-inhibitor complex masks antigenic sites on the active enzyme (Cīr). Therefore, a diminution of $\mathrm{Cl} r$ antigenic reactivity in the test is an indication of Cî-INA-Cîr complex formation, which in turn is an indication of prior $\mathrm{Cl}$ activation. Fig. 5 shows that incubation of serum with smoke solution did not result in a loss of antiC1r reactivity, which was identical to that observed using buffered-treated serum. These results were obtained in both single radial immunodiffusion (Fig. $5 A$ ) and Ouchterlony double diffusion tests (Fig. $5 B$ ). In contrast, serum treated with aggregated IgG, a known activator of $\mathrm{Cl}$ and the classical pathway, showed a marked reduction in its reaction with anti$\mathrm{Clr}$ in both tests (Figs. $5 A$ and $B$ ).

The effect of smoke on hemolytic levels of serum $\mathrm{C4}$ is shown in Fig. 6. Aqueous solutions of unfiltered cigarette smoke totally depleted C4 activity of serum, as did treatment with aggregated IgG. Serum incubated with buffer retained full C4 activity. Although this result appears to be in conflict with the preceeding data which indicated absence of classical pathway activation by cigarette smoke, the effect of smoke on serum C4 may be explained by the fact that an internal thiolester bond is present in this protein as well as in C3 (34). This point will be discussed in further detail below.

Effect of smoke on C3 cleavage by Factors $H$ and I. Since it appeared that smoke treatment produced a modified form of $\mathrm{C} 3$ that is capable of activating the alternative pathway, we proceeded to test whether smoke-treated C3 was susceptible to inactivation by the complement regulatory proteins, Factors $\mathrm{H}$ and $\mathrm{I}$. Factor $\mathrm{H}$ has the ability to bind to $\mathrm{C} 3 \mathrm{~b}$ and " $\mathrm{C} 3 \mathrm{~b}$ like" C3 (a form of C3 activated by thiolester cleavage, e.g.,

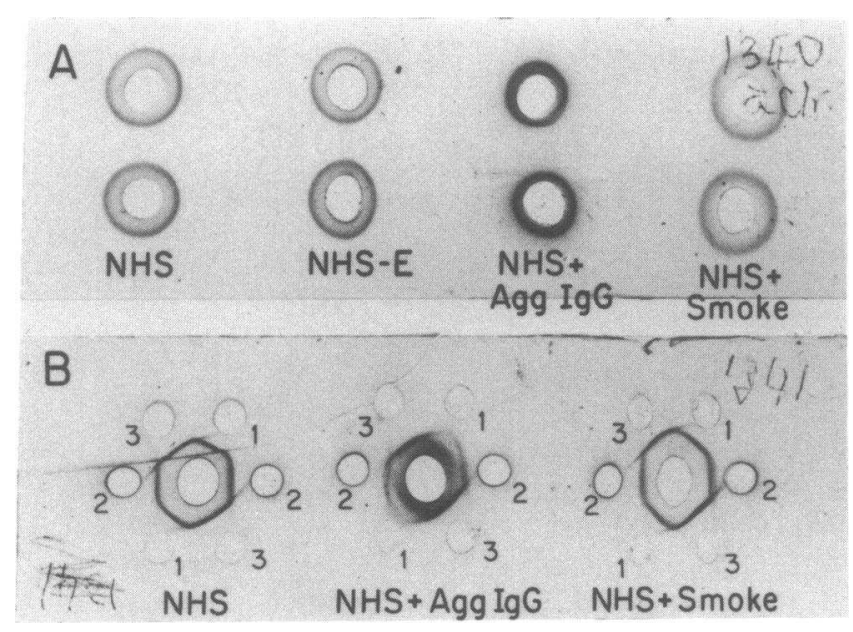

Figure 5. Effect of whole smoke solution on serum C1. NHS $(0.1 \mathrm{ml})$ was treated with an equal volume of PBS (NHS), 0.01 M EDTA (NHS-E), $2 \mathrm{mg} / \mathrm{ml}$ aggregated IgG (NHS + Agg IgG), or an equal volume of whole smoke solution (NHS + smoke). All samples were incubated for $60 \mathrm{~min}$ at $37^{\circ} \mathrm{C}$ before their application to the immunodiffusion plates. $(A)$ Radial immunodiffusion was carried out in $1 \%$ agarose containing $0.03 \mathrm{M}$ potassium phosphate ( $\mathrm{pH} 8.0$ ), $0.1 \mathrm{M}$ $\mathrm{NaCl}, 0.01 \mathrm{M}$ EDTA, and an appropriate dilution of anti-Clr. $(B)$ Double diffusion of the above samples vs. anti-C1r (1), anti-C1s (2), and anti-Clq (3). Diffusion in both $(A)$ and $(B)$ proceeded for 48 $h$ at $4^{\circ} \mathrm{C}$; gels were then soaked in $0.9 \% \mathrm{NaCl}+0.1 \%$ sodium azide, dried, and stained with Amido black.

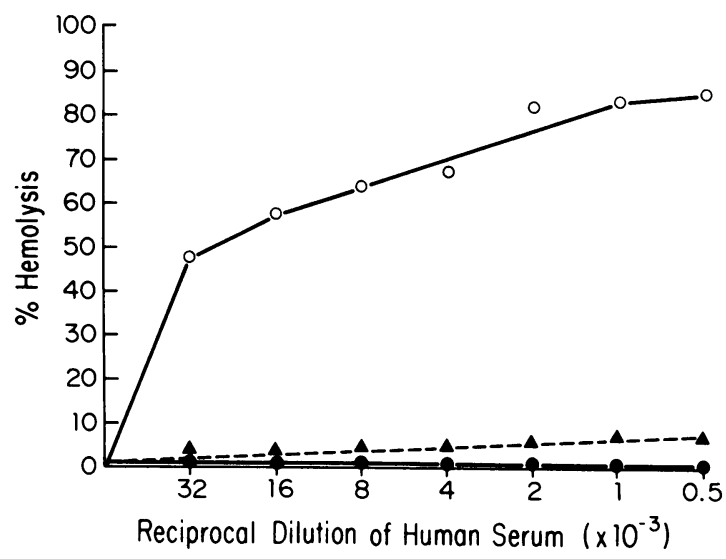

Figure 6. Hemolytic titration of serum C4. $0.05 \mathrm{ml}$ of NHS was pretreated with either $0.05 \mathrm{ml}$ of whole smoke solution (- - -), $0.02 \mathrm{ml}$ of aggregated $\mathrm{IgG}(10 \mathrm{mg} / \mathrm{ml})\left(---\Delta_{---}\right)$, or $0.05 \mathrm{ml}$ of PBS (-O -) for $60 \mathrm{~min}$ at $37^{\circ} \mathrm{C}$. After pretreatment, the serum mixtures were diluted as indicated with $\mathrm{SGVB}^{2+}$, and $0.5 \mathrm{ml}$ of each sample was then added to $0.2 \mathrm{ml}$ of $1.5 \times 10^{8} / \mathrm{ml} \mathrm{EACl}$ and incubated for $10 \mathrm{~min}$ at $37^{\circ} \mathrm{C}$. Next, $0.03 \mathrm{ml}$ of $\mathrm{C} 2(20 \mathrm{ug} / \mathrm{ml})$ was added to each sample and the incubation continued for $10 \mathrm{~min}$ at $37^{\circ} \mathrm{C}$. Finally, $2.2 \mathrm{ml}$ of a 1:50 dilution of guinea pig serum containing $0.04 \mathrm{M}$ EDTA in GVB was added and samples were incubated for an additional $60 \mathrm{~min}$ at $37^{\circ} \mathrm{C}$. The percent hemolysis was measured as absorbance of free hemoglobin at $412 \mathrm{~nm}$.

methylamine), but not to native $\mathrm{C} 3$. After binding, Factor $\mathbf{H}$ acts as a cofactor for proteolytic cleavage of the alpha chain of C3 by Factor I (35). Fig. 7 demonstrates that smoke-treated C3 showed partial cleavage of its alpha chain (lane 4) qualitatively similar to (but not quantitatively comparable with) methylamine-treated C3, in which there was substantial cleavage of the alpha chain to the predicted 76- and $43-\mathrm{kD}$ fragments (lane 2). Under the same conditions, C3 treated with buffer (lane 6) showed almost no cleavage of its alpha chain. In the case of the buffer control, the small amount of cleavage observed was probably due to $\mathrm{C} 3\left(\mathrm{H}_{2} \mathrm{O}\right)$, a "C3b-like" $\mathrm{C} 3$ that could have formed spontaneously during the incubation and dialysis period. Densitometric analysis of this gel revealed that alpha chain cleavage and appearance of the 76- and 43-kD products from C3 treated with smoke were intermediate in amount between those of methylamine and buffer-treated C3.

Binding of radioiodinated Factor $\mathrm{H}$ to smoke-treated $\mathrm{C} 3$. Since smoke-treated C3 was not quantitatively comparable with methylamine-treated C3 with respect to alpha chain cleavage by Factors $\mathrm{H}$ and I, we chose next to test whether $\mathrm{C} 3$ treated with whole smoke solution was capable of binding ${ }^{125} \mathrm{I}$ Factor $\mathrm{H}$. In this assay, the binding of Factor $\mathrm{H}$ is competitive between EC3b and fluid-phase "C3b-like" C3 (produced by methylamine treatment) or true $\mathrm{C} 3 \mathrm{~b}$. The greater the binding of ${ }^{125} \mathrm{I}$-Factor $\mathrm{H}$ to fluid-phase "C3b-like" $\mathrm{C} 3$ or $\mathrm{C} 3 \mathrm{~b}$, the lower is its binding to EC3b. Table I shows that methylaminetreated $\mathrm{C} 3$, like $\mathrm{C} 3 \mathrm{~b}$, competed for ${ }^{125} \mathrm{I}$-Factor $\mathrm{H}$; however, smoke-treated $\mathrm{C} 3$ bound substantially less Factor $\mathrm{H}$ as did buffer-treated C3. This data supports the previous observation concerning cleavage of smoke-treated $\mathrm{C} 3$ by Factors $\mathrm{H}$ and I and is further evidence that smoke-treated $\mathrm{C} 3$, while capable of activating the alternative pathway of complement, is not entirely comparable in its functional behavior to methylaminetreated C3.

Effect of smoke on the incorporation of radiolabeled me- 


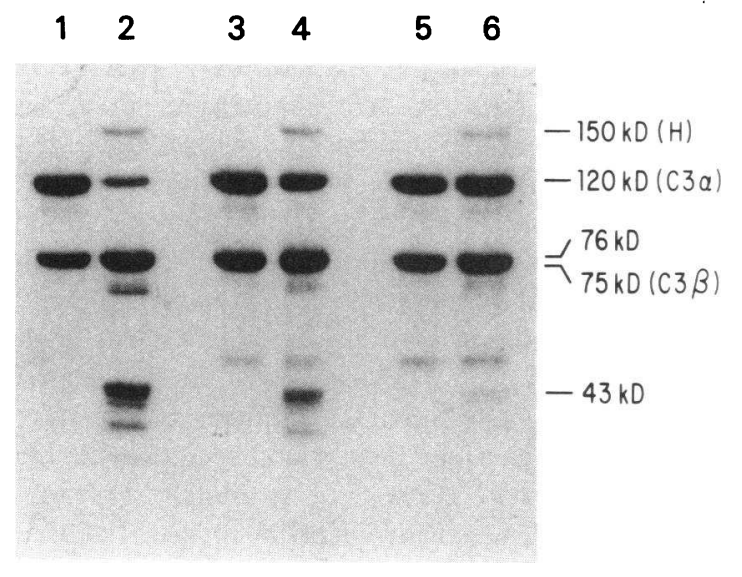

Figure 7. SDS-PAGE analysis of the cleavage of treated $\mathrm{C} 3$ by Factors $\mathrm{H}$ and $\mathrm{I}$. Samples of $\mathrm{C} 3(0.1 \mathrm{ml}$ at $1.6 \mathrm{mg} / \mathrm{ml})$ were pretreated for $60 \mathrm{~min}$ at $37^{\circ} \mathrm{C}$ with an equal volume of whole smoke solution, PBS, or $50 \mathrm{mM}$ methylamine (final concentration) and subsequently dialyzed against PBS at $4^{\circ} \mathrm{C}$. Lane $1, \mathrm{C} 3$ pretreated with methylamine; lane 3, C3 pretreated with whole smoke solution; lane 5, C3 pretreated with PBS. Aliquots of the above treated samples were also reacted with Factors $\mathrm{H}(50 \mu \mathrm{g})$ and $\mathrm{I}(3.4 \mu \mathrm{g})$ for $45 \mathrm{~min}$ at $37^{\circ} \mathrm{C}$. Lane 2, C3-methylamine plus Factors $\mathrm{H}$ and $\mathrm{I}$; lane 4, C3smoke plus Factors $\mathrm{H}$ and I; lane 6, C3-buffer plus Factors $\mathrm{H}$ and $\mathrm{I}$. $\sim 10 \mu \mathrm{g}$ of protein was applied to each lane and electrophoresed in 8.5\% polyacrylamide under reducing conditions (1\% 2-mercaptoethanol). The gel was subsequently stained with Amido black. The two chains of reduced native $\mathrm{C} 3$ are observed at $120 \mathrm{kD}$ (alpha chain) and $75 \mathrm{kD}$ (beta chain). Factors $\mathrm{H}$ - and I-generated cleavage products of the alpha chain of $\mathrm{C} 3$ are present at $76 \mathrm{kD}$ (not readily observed in the figure) and $43 \mathrm{kD}$ (observed in the figure). Additional Factor I-generated alpha chain cleavage products are seen below the 43-kD band. Factor $\mathrm{H}$ is observed as a single band at $150 \mathrm{kD}$; the concentration of Factor I was below the level of detection. Note that diminution of the alpha chain and subsequent appearance of the 43-kD cleavage product is minimal after reaction of buffer-treated C3 (negative control) with Factors $\mathrm{H}$ and $\mathrm{I}$. By contrast, there is substantial diminution of the alpha chain and appearance of a $43-\mathrm{kD}$ cleavage product after methylamine-treated $\mathrm{C} 3$ (positive control) is reacted with Factors $\mathrm{H}$ and $\mathrm{I}$. Smoke-treated $\mathrm{C} 3$ undergoes partial alpha chain cleavage when incubated with Factors $\mathrm{H}$ and $\mathrm{I}$, which is qualitatively but not quantitatively similar to methylaminetreated C3.

thylamine and iodoacetamide by C3. Finally, we tested whether smoke-modified C3 bound radiolabeled methylamine or iodoacetamide to determine whether the thiolester bond in C3 remained intact or was cleaved after smoke treatment. Methylamine cleaves this thiolester bond and binds to the nascent carbonyl group. Therefore, following methylamine treatment of $\mathrm{C} 3,\left[{ }^{14} \mathrm{C}\right]$ iodoacetamide is incorporated (reaction with the nascent free thiol) but $\left[{ }^{14} \mathrm{C}\right]$ methylamine is not (thiolester bond is already broken). The data in Table II show that smoke-treated $\mathrm{C} 3$ bound $\left[{ }^{14} \mathrm{C}\right]$ methylamine at a molar ratio of 0.76 (theoretical predicted value for an intact thiolester would be 1.0), suggesting that smoke treatment does not appreciably cleave the thiolester in $\mathrm{C} 3$. In addition, smoke-treated C3 did not bind $\left[{ }^{14} \mathrm{C}\right]$ iodoacetamide, whereas methylamine-treated $\mathrm{C} 3$ did (data not shown). However, this last observation must be interpreted with caution because cigarette smoke contains numerous components which will quickly react with a free sulfhydryl group, thus masking its detection. Indeed, we ob-
Table I. Binding of Radioiodinated Factor $\mathrm{H}$ to Smoke-Treated $\mathrm{C3}$

\begin{tabular}{|c|c|}
\hline Fluid-phase competitor & Percent ${ }^{125} \mathrm{I}$-Factor $\mathrm{H}$ bound to $\mathrm{EC} 3 \mathrm{~b}$ \\
\hline None & 100 \\
\hline C3-PBS & $71.4 \pm 5.7$ \\
\hline C3-smoke & $62.0 \pm 2.1$ \\
\hline C3-methylamine & $45.6 \pm 11.1$ \\
\hline $\mathrm{C} 3 \mathrm{~b}$ & $39.8 \pm 3.6$ \\
\hline
\end{tabular}

The data are given as percent of $100 \mathrm{ng}$ of ${ }^{125} \mathrm{I}-\mathrm{Factor} \mathrm{H}(0.5 \mathrm{mCi} /$ $\mathrm{mg}$ ) bound to $5 \times 10^{7} \mathrm{EC} 3 \mathrm{~b}$ in the presence of $2.0 \mu \mathrm{g}$ of fluid-phase C3 competitors in a total volume of $0.1 \mathrm{ml}$ in $\mathrm{SGVB}^{2+}$. The C3, EC3b, and ${ }^{125} \mathrm{I}$-Factor $\mathrm{H}$ mixtures were incubated for $10 \mathrm{~min}$ at room temperature. The mixtures were then layered onto $0.3 \mathrm{ml}$ of $20 \%$ sucrose in $\mathrm{SGVB}^{2+}$; cells were then rapidly pelleted using a microfuge. The bottoms of the microfuge tubes were cut off and the pellets counted for bound ${ }^{125} \mathrm{I}$. C3b was prepared by trypsinization of C3, as described in Methods, and used as the positive control. Values represent mean $\pm \mathrm{SD}$ of triplicate assays.

served that $\mathrm{C} 3$ pretreated with methylamine, and subsequently treated with either smoke solution or buffer (PBS), will bind $\left[{ }^{14} \mathrm{C}\right]$ iodoacetamide in the latter case $(\sim 1 \mathrm{~mol}$ of iodoacetamide/ mol of $\mathrm{C3}$ ), but will no longer incorporate $\left[{ }^{14} \mathrm{C}\right]$ iodoacetamide after smoke exposure (data not shown).

\section{Discussion}

In this paper, we present evidence showing that cigarette smoke is capable of activating the alternative pathway of complement in vitro. This finding confirms observations in two recent reports which showed that cigarette smoke condensate (tar fraction) activates complement in vitro $(19,20)$. Such results, along with our preliminary report of complement-dependent increases in chemotactic activity in the lung washings of smoke-exposed rats (18), raise the possibility that smoke-

Table II. Effect of Smoke on the Incorporation of $\left[{ }^{14} \mathrm{C}\right]$ Methylamine by $\mathrm{C3}$

\begin{tabular}{lll}
\hline $\begin{array}{l}\text { Pretreatment } \\
\text { of C3 }\end{array}$ & $\begin{array}{l}\text { Disintegrations per minute/ } \\
0.32 \mathrm{mg} \mathrm{C3}\end{array}$ & {$\left[{ }^{14} \mathrm{C}\right]$ methylamine/C3 } \\
\hline & & $\mathrm{mol} / \mathrm{mol}$ \\
None & $192,334 \pm 4726$ & 1.10 \\
Buffer (PBS) & $189,014 \pm 3231$ & 1.08 \\
Whole smoke & $132,425 \pm 4423^{*}$ & 0.76 \\
Methylamine & $13,322 \pm 1657$ & 0.08 \\
\hline
\end{tabular}

$0.5 \mathrm{ml}$ of $\mathrm{C} 3(2.5 \mathrm{mg} / \mathrm{ml})$ was treated with $0.25 \mathrm{ml}$ of whole smoke solution, $50 \mathrm{mM}$ methylamine (final concentration), or $0.25 \mathrm{ml}$ of PBS for $60 \mathrm{~min}$ at $37^{\circ} \mathrm{C}$. Following an exhaustive dialysis at $4^{\circ} \mathrm{C}$ against $P B S$, the treated $C 3$ was reacted with $4 \mathrm{mM}$ $\left[{ }^{14} \mathrm{C}\right]$ methylamine $(46 \mathrm{mCi} / \mathrm{mmol})$ for $4 \mathrm{~h}$ at $37^{\circ} \mathrm{C}$ as described in Methods. Values represent mean \pm SD of quadruplicate assays.

* Corrected for incorporation of label by nondialyzable smoke components (mol wt $>50,000$ ). (Values obtained after treating dialyzed smoke alone with $4 \mathrm{mM}\left[{ }^{14} \mathrm{C}\right]$ methylamine were subtracted from values obtained after reacting dialyzed mixtures of smoke and C3 with the isotope.) 
induced complement activation may also occur in humans. Should this prove true, chronic, low-grade activation of complement in the lung fluids of smokers could be an important initiating step in the pathogenesis of small airway inflammation in such individuals. Small airway inflammation, in turn, is thought to be a pathogenetic factor in the development of pulmonary emphysema $(2,3)$.

The factor(s) in cigarette smoke which deplete the hemolytic activity of serum and also produce a form of C3 that can activate the alternative pathway appear to have a mol wt $<1,000$ and are found only in whole smoke. Numerous small nucleophiles, including methylamine and hydrazine (both of which can cleave thiolester bonds and produce "C3b-like" C3), are present in cigarette smoke $(1,36,37)$. One would expect these substances to be found in the gas phase of smoke, which we report to be inactive, but at the $\mathrm{pH}$ of cigarette smoke $(\sim 6.0)$, volatile amines are protonated and thus are found in the particulate phase (1). However, the observed effect of smoke on complement cannot be due to the action of these individual smoke components since their concentration in cigarette smoke is far too low to explain the results. For example, using the published values of $4.6 \mu \mathrm{g}$ methylamine and $30 \mathrm{ng}$ hydrazine/cigarette $(1,37)$, our smoke solution, prepared as described in Methods, contains $\sim 0.9 \mathrm{mM}$ methylamine and $5.6 \mu \mathrm{M}$ hydrazine (compare these concentrations with the effective concentration range for methylamine shown in Figs. 1 and 2). In addition, ammonia, at concentrations found in cigarette smoke, had no effect on serum complement, although it has previously been reported that higher concentrations $(50 \mathrm{mM})$ of ammonia resulted in $50 \%$ production of "C3b-like" C3 after a 60-min incubation (31).

C3 treated with smoke, like methylamine-treated C3, has no change in molecular weight as determined by SDS-PAGE. In contrast to methylamine treatment, smoke-treated $\mathrm{C} 3$ has increased anodal mobility in agarose electrophoresis, indicating a more negatively charged molecule. Whether this is due to a secondary (artifactual) effect of cigarette smoke or is essential for the smoke-induced activating capacity of $\mathrm{C} 3$ is currently being investigated.

Smoke-treated $\mathrm{C} 3$ apparently does not bind Factor $\mathrm{H}$ as do "C3b-like" C3 or C3b and this may explain why C3 smoke is only partially susceptible to the action of Factors $\mathrm{H}$ and $\mathrm{I}$ in contrast to methylamine-treated C3. (Incidentally, poor binding of Factor $\mathrm{H}$ to smoke-modified $\mathrm{C} 3$ would theoretically facilitate complement activation.) Further, smoke-treated C3, like buffer-treated $\mathrm{C} 3$, incorporates radiolabeled methylamine but not iodoacetamide, while $\mathrm{C} 3$ treated with methylamine yields the opposite results. For all these reasons, it can be suggested that the modified form of $\mathrm{C} 3$ produced by cigarette smoke is probably different from that produced by methylamine, although both forms can activate the alternative pathway of complement. However, our data do not rule out the possibility that some $\mathrm{C} 3$ molecules undergo thiolester cleavage after exposure to cigarette smoke (see partial cleavage of smoke-treated $\mathrm{C} 3$ by Factors $\mathrm{H}$ and I, Fig. 7; see also the $25 \%$ decrease in incorporation of $\left[{ }^{14} \mathrm{C}\right]$ methylamine by $\mathrm{C} 3$ after smoke treatment, Table II).

Although smoke does not activate $\mathrm{Cl}$, indicating that it does not activate the classical complement pathway, smoke completely consumes serum $\mathrm{C} 4$. Since $\mathrm{C} 4$, like $\mathrm{C} 3$, contains an internal thiolester bond (34), cigarette smoke may directly consume $\mathrm{C} 4$ by cleaving its thiolester without activating the classical pathway. Alternatively, since C3 and C4 share a considerable degree of homology in the primary sequence of their alpha chains $(38,39)$, this could render both molecules susceptible to smoke-induced modifications by a thiolesterindependent mechanism. Such possibilities remain to be tested.

We have shown that exposure of $\mathrm{C} 3$ to smoke solution produces a functionally modified form of the molecule which is capable of activating the alternative pathway of complement. It remains unclear whether this smoke-modified C3 is similar to methylamine-treated $\mathrm{C} 3$ in that its internal thiolester bond is broken or whether smoke treatment produces a heretofore unrecognized form of $\mathrm{C} 3$ which has the ability to activate the alternative pathway without cleavage of its thiolester. Clearly, however, smoke-treated C3 is not identical to methylaminetreated C3.

Cigarette smoke is a complex mixture of over 4,000 known chemicals $(1,36)$. We are currently attempting to fractionate smoke to separate possible complement activators from other "interfering" components. Future studies with isolated fractions of cigarette smoke may enable us to identify the chemical mechanism involved in smoke-induced complement activation.

\section{Acknowledgments}

The authors wish to thank Dr. Hans Müller-Eberhard and Dr. Michael Pangburn from the Scripps Clinic and Research Foundation, La Jolla, CA; Dr. Müller-Eberhard for suggesting the $\left[{ }^{14} \mathrm{C}\right]$ methylamine incorporation experiment, and Dr. Pangburn for generously providing the purified Factor $\mathrm{H}$ used in the competitive binding experiment.

This investigation was supported by grants HL-14262, ES-07088, and AI-18526 from the U. S. Public Health Service.

\section{References}

1. U. S. Public Health Service. 1979. Smoking and Health: A Report of the Surgeon General. Department of Health, Education, and Welfare publication no. (PHS) 70-50066. U. S. Government Printing Office, Washington, DC.

2. Hoidal, J. R., and D. E. Niewoehner. 1983. Pathogenesis of emphysema. Chest. 83:679-685.

3. Janoff, A. 1983. Biochemical links between cigarette smoking and pulmonary emphysema. J. Appl. Physiol.: Respir. Environ. Exercise Physiol. 55:285-293.

4. Janoff, A. 1978. Granulocyte elastase: role in arthritis and pulmonary emphysema. In Neutral Proteases of Human Polymorphonuclear Leukocytes. K. Havemann and A. Janoff, editors. Urban and Schwarzenberg, Inc., Baltimore. 380-417.

5. Rodriguez, R. J., R. R. White, R. M. Senior, and E. A. Levine. 1977. Elastase release from human alveolar macrophages, comparison between smokers and nonsmokers. Science (Wash. DC). 198:313-314.

6. Hinmann, L. M., C. A. Stevens, R. A. Matthay, and J. B. L. Gee. 1980. Elastase and lysozyme activities in human alveolar macrophages. Effects of cigarette smoking. Am. Rev. Respir. Dis. 121:263271.

7. Hoidal, J. R., R. B. Fox, P. A. Lemarbe, R. Porr, and J. E. Repine. 1981. Altered oxidative metabolic responses in vitro of alveolar macrophages from asymptomatic cigarette smokers. Am. Rev. Respir. Dis. 123:263-271.

8. Reynolds, H. Y. 1983. Lung inflammation: role of endogenous chemotactic factors in attracting polymorphonuclear granulocytes. Am. Rev. Respir. Dis. 127:516-525.

9. Kazmierowski, J. A., J. I. Gallin, and H. Y. Reynolds. 1980. Mechanisms for the inflammatory response in primate lungs. Demonstration and partial characterization of an alveolar macrophage chemotactic factor with preferential activity for polymorphonuclear leukocytes. J. Clin. Invest. 59:273-281. 
10. Hunninghake, G. W., J. E. Gadek, H. W. Fales, and R. G. Crystal. 1980. Human alveolar macrophage-derived chemotactic factor for neutrophils. J. Clin. Invest. 66:473-483.

11. Merrill, W. W., G. P. Naegel, R. A. Matthay, and H. Y. Reynolds. 1980. Alveolar macrophage derived chemotactic factor. Kinetics of in vitro production and partial characterization. J. Clin. Invest. 65:268-276.

12. Cohen, A. B., D. E. Chenoweth, and T. E. Hugli. 1982. The release of elastase, myeloperoxidase, and lysozyme from human alveolar macrophages. Am. Rev. Respir. Dis. 126:241-247.

13. Postlehwaite, A. E., and A. H. Kang. 1976. Collagen and collagen peptide-induced chemotaxis of human blood monocytes. $J$. Exp. Med. 143:1299-1307.

14. Norris, D. A., R. A. F. Clark, L. M. Swigart, J. C. Huff, L. Weston, and S. E. Howell. 1982. Fibronectin fragment(s) are chemotactic for human peripheral blood monocytes. J. Immunol. 129:1612-1618.

15. Senior, R. M., G. L. Griffin, and R. P. Mecham. 1980. Chemotactic activity of elastin-derived peptides. J. Clin. Invest. 66: 859-862.

16. Reid, K. B. M., and R. R. Porter. 1981. The proteolytic activation systems of complement. Annu. Rev. Biochem. 50:433-464.

17. Totti, N., K. T. McCusker, E. J. Campbell, G. L. Griffin, and R. M. Senior. 1984. Nicotine is chemotactic for neutrophils and enhances neutrophil responsiveness to chemotactic peptides. Science (Wash. DC). 223:169-171.

18. Kew, R. R., A. Janoff, and B. Ghebrehiwet. 1983. Cleavage of the third component of complement (C3) in lung fluids after acute cigarette smoke inhalation. Am. Rev. Respir. Dis. 127(4, pt. 2):154. (Abstr.)

19. Firpo, A., M. J. Polley, and C. G. Becker. 1983. The effect of tobacco derived products on the human complement system. Immunobiology. 164(3/4):318. (Abstr.)

20. Perricone, R., C. DeCarolis, G. DeSanctis, and L. Fontana. 1983. Complement activation by cigarette smoke condensate and tobacco infusion. Arch. Environ. Health. 38:176-179.

21. Tack, B. F., and J. W. Prahl. 1976. Third component of complement: purification from plasma and physiochemical characterization. Biochemistry. 15:4513-4521.

22. Janatova, J., B. F. Tack, and J. W. Prahl. 1980. Third component of human complement: structural requirements for its function. Biochemistry. 19:4479-4485.

23. Pangburn, M. K., R. D. Schreiber, and H. J. Müller-Eberhard. 1977. Human complement C3b inactivator: isolation, characterization, and demonstration of an absolute requirement for the serum protein beta-1 $\mathrm{H}$ for cleavage of $\mathrm{C} 3 \mathrm{~b}$ and $\mathrm{C} 4 \mathrm{~b}$ in solution. J. Exp. Med. 146: 257-270.

24. Müller-Eberhard, H. J., and H. G. Kunkel. 1961. Isolation of a thermolabile serum protein which precipitates gamma-globulin aggregates and participates in immune hemolysis. Proc. Soc. Exp. Biol. Med. 106:291-295.

25. Lowry, O. H., N. J. Roseborough, A. L. Farr, and R. J.
Randall. 1951. Protein measurement with the folin phenol reagent. $J$. Biol. Chem. 193:265-275.

26. Carp, H., and A. Janoff. 1978. A possible mechanism of emphysema in smokers. In vitro suppression of serum elastase-inhibitory capacity by fresh cigarette smoke and its prevention by antioxidants. Am. Rev. Respir. Dis. 118:617-621.

27. Guerin, M. R., W. L. Maddox, and J. R. Stokely. 1975. Tobacco smoke inhalation exposure: concepts and devices. In Proceedings of Tobacco Smoke Inhalation Workshop on Experimental Methods in Smoking and Health Research. G. B. Gori, editor. Department of Health, Education, and Welfare Publication no. (NIH) 75-906. U. S. Government Printing Office, Washington, DC. 31-48.

28. Laemmli, U. K. 1970. Cleavage of structural proteins during the assembly of the head of bacteriophage T4. Nature (Lond.). 227: 680-685.

29. Cooper, N. R., and H. J. Müller-Eberhard. 1968. A comparison of methods for the molecular quantitation of the fourth component of human complement. Immunochemistry. 5:155-169.

30. Ziccardi, R. J., and N. R. Cooper. 1980. Development of an immunochemical test to assess $\mathrm{Cl}$ inactivator function in human serum and its use for the diagnosis of hereditary angioedema. Clin. Immunol. Immunopathol. 15:465-471.

31. Pangburn, M. K., and H. J. Müller-Eberhard. 1980. Relation of a putative thiolester bond in $\mathrm{C} 3$ to activation of the alternative pathway and the binding of $\mathrm{C} 3 \mathrm{~b}$ to biological targets of complement. J. Exp. Med. 152:1102-1114.

32. Pangburn, M. K., and H. J. Müller-Eberhard. 1978. Complement C3 convertase: cell surface restriction of beta- $1 \mathrm{H}$ control and generation of restriction on neuraminidase-treated cells. Proc. Natl. Acad. Sci. USA. 75:2416-2420.

33. Janatova, J., P. E. Lorenz, A. N. Schechter, J. W. Prahl, and B. F. Tack. 1980. Third component of human complement: appearance of a sulfhydryl group following chemical or enzymatic inactivation. Biochemistry. 19:4471-4478.

34. Janatova, J., and B. F. Tack. 1981. Fourth component of human complement: studies of an amine-sensitive site comprised of a thiol component. Biochemistry. 20:2394-2402.

35. Davis, A. E., and R. A. Harrison. 1982. Structural characterization of Factor I mediated cleavage of the third component of complement. Biochemistry. 21:5745-5749.

36. Stedman, R. L. 1968. The chemical composition of tobacco and tobacco smoke. Chem. Rev. 68:153-207.

37. Schmeltz, I., and D. Hoffmann. 1977. Nitrogen-containing compounds in tobacco and tobacco smoke. Chem. Rev. 77:295-311.

38. Janatova, J. 1983. The third (C3) and fourth (C4) components of complement: labile binding site and covalent bond formation. Ann. NY Acad. Sci. 421:218-234.

39. Campbell, R. D., J. Gagnon, and R. R. Porter. 1981. Amino acid sequence around the proposed thiolester bond of human complement component $\mathrm{C} 4$ and comparison with the corresponding sequences from C3 and alpha 2-macroglobulin. Biosci. Rep. 1:423-429. 